\title{
Learning from the enemy NATO as a model for the Warsaw Pact
}

\section{Working Paper}

\author{
Author(s): \\ Mastny, Vojtech \\ Publication date: \\ 2001
}

Permanent link:

https://doi.org/10.3929/ethz-a-004148840

\section{Rights / license:}

In Copyright - Non-Commercial Use Permitted

\section{Originally published in:}

Zürcher Beiträge zur Sicherheitspolitik und Konfliktforschung 58 

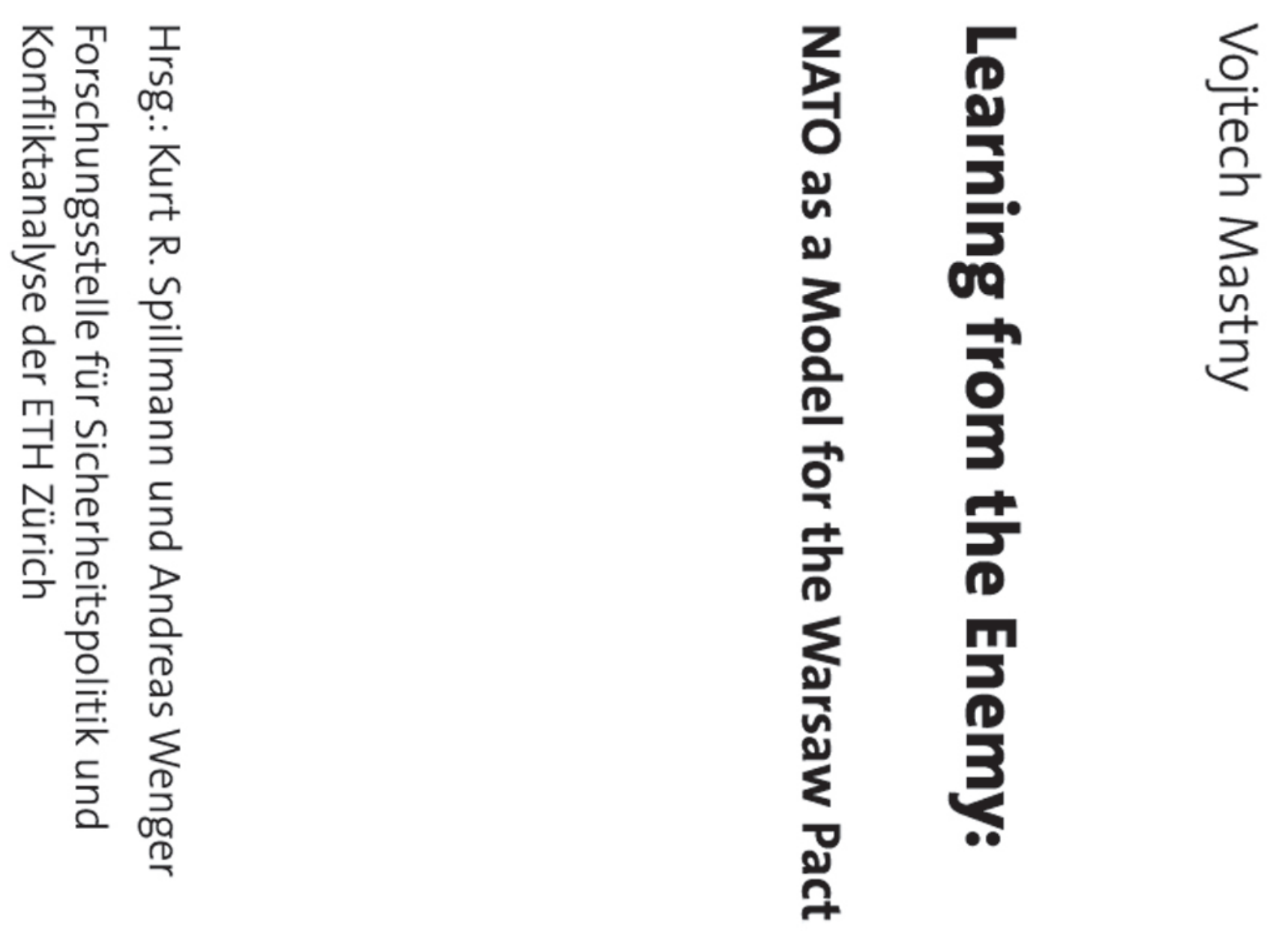


\section{Zürcher Beiträge}

zur Sicherheitspolitik und Konfliktforschung Nr. 58

Vojtech Mastny

Learning from the Enemy

NATO as a Model for the Warsaw Pact 


\section{Contents}

Preface

Introduction

7

1 The Creation of the Warsaw Pact (1955-65)

9

2 The Reform of the Warsaw Pact (1966-69)

19

3 The Demise of the Warsaw Pact (1969-91)

Conclusions

Abbreviations

Bibliography 


\section{Preface}

In 1955, the Warsaw Pact was created as a mirror image of NATO that could be negotiated away if favorable international conditions allowed the Soviet Union to benefit from a simultaneous dissolution of both alliances. Such conditions never materialized and the Warsaw Pact gradually evolved into an alliance in its own right, but remained haunted by the image of its Western counterpart. Some of the Soviet Union's Eastern European dependents, particularly Poland, invoked the NATO model in trying to make their involuntary alliance closer to an alliance of equals. The Soviet Union itself looked upon the model as it sought to increase the cohesion and effectiveness of the organization. Because of structural and political impediments, however, none of the attempts to remodel it along NATO lines worked, and the last one, in 1987, precipitated the Warsaw Pact's final disintegration four years later. Regardless of the differences between the two alliances, the Warsaw Pact's inability to strike the right balance between its military and political functions provides a cautionary tale for NATO as well.

The author of this study, Prof. Dr. Vojtech Mastny, Senior Research Scholar at the Woodrow Wilson International Center for Scholars in Washington DC, has been Professor of History and International Relations at Columbia University, the University of Illinois, Boston University, and the Johns Hopkins University School of Advanced International Studies. He was also Professor of Strategy at the U.S. Naval War College in Newport and Fulbright professor at the University of Bonn. In 1996-98, he was the first Manfred Wörner Fellow of NATO. His books include The Helsinki Process and the Reintegration of Europe, The Czechs Under Nazi Rule, Russia's Road to the Cold War, and most recently, The Cold War and Soviet Insecurity, the winner of the American Historical Association's 1997 George L. Beer Prize.

Vojtech Mastny's essay about the history of the two Cold War alliances fits perfectly into the series "Zürcher Beiträge zur Sicherheitspolitik und Konfliktforschung". The author is, in his function as project

coordinator of the Parallel History Project on NATO and the Warsaw Pact (PHP), closely connected with the Center for Security Studies and Conflict Research (CSS) at the ETH Zürich. The CSS launched the PHP in 1999 together with the National Security Archive and the Cold War International History Project in Washington, DC, and the Institute of Military History, in Vienna.

Even though the Cold War is over, most military documents from this period are still being withheld for alleged or real security reasons. To bridge this gap, the PHP seeks to declassify, evaluate, and disseminate the military records of archives in both NATO and former Warsaw Pact countries. Based on this new evidence, it provides fresh analyses and aims at writing a "parallel" history of the Cold War alliances. A close look at the impact of NATO on the Warsaw Pact, as presented in the following essay by Vojtech Mastny, promotes a new understanding of the linkage between military power and political purpose. Ideally, this will help advance an essentially different meaning of security.

May, 2001

Prof. Dr. Kurt R. Spillmann

Director of the Center

for Security Studies and

Conflict Research
Prof. Dr. Andreas Wenger

Deputy Director of the Center for Security Studies and Conflict Research 


\section{INTRODUCTION}

In accounting for NATO's longevity compared with the Warsaw Pact, it has been usual to contrast the virtues of a voluntary alliance of equals with the vices of one resting upon coercion by its strongest member. Yet however accurate the comforting comparison is as a superficial description of the obvious, it tends to obscure other important differences between the two military groupings, their particular internal dynamics, as well as the specific, as distinguished from general, reasons for their different fates. In fact, as long as the Cold War lasted, with no end in sight, NATO worried that it was precisely its democratic nature that put it at a disadvantage with the Warsaw Pact, run by Moscow with an iron fist.

With the files of the communist alliance gradually opening, it is now also possible to grasp what worried its leaders about NATO. Not only was their image of NATO as a threat a staple of their propaganda but they took it for granted in their internal communications. Although the exact nature of the threat was never entirely clear in their muddled Marxist minds, the Western alliance nevertheless posed for them a challenge they incessantly grappled with. NATO's successes that eluded their own alliance further magnified the challenge, suggesting that something useful might be learned from the enemy.

The essay that follows considers NATO as a model for the Warsaw Pact during three different stages of its development. The first was that of its unfinished creation until the mid-nineteen sixties, when the definition of its purpose was still at issue. In the latter part of the decade, the parallel crises of both alliances provided an impetus for a reform of the Warsaw Pact to make it more effective. With the reform accomplished in 1969, the subsequent period of consolidation during the rise and fall of East-West détente concealed the communist alliance's persisting weaknesses, leading eventually to its demise despite efforts to save it by adapting it to NATO. 


\section{The Creation of the Warsaw Pact (1955-65)}

Stalin's initial assessments of NATO were both simplistic and wrong. ${ }^{1}$ Having at first deprecated it as little more than an instrument of Wall Street for the harnessing of Western Europe, he became prone to panic once the alliance began to gain military substance in response to the communist aggression in Korea, opening up the dreaded prospect of the inclusion of West Germany in the US-built defense system. Only after his successor, Nikita S. Khrushchev, decided to cut Soviet losses by accommodating to West Germany's admission into NATO was the door open to a reassessment. Its remarkable result was the creation in 1955 of the Warsaw Pact, modeled closely after NATO. ${ }^{2}$

Similarities between the document signed in Warsaw on 14 May 1955 and NATO's founding charter of 4 April 1949, have sometimes been noted but never adequately explained. They included the declaration by the signatories of their intent to refrain from the use or threat of force, the almost identical description of the mutual consultations they vowed to conduct in case of an enemy attack, their explicit-if qualifiedpledge to assist each other against such an attack by "all the means deemed necessary," and the compatibility of their treaty with any of their other obligations. Less crucial, but still important, affinities between the two treaties concerned their invoking the principles of the UN Charter, their twenty-year validity, and their provisions for

1 Nataliia I. Egorova, "NATO i evropeiskaia bezopasnost: Vospriiatie sovetskogo rukovodstva" [NATO and European Security: Soviet Leadership Perceptions], in Stalin i kholodnaia voina [Stalin and the Cold War], ed. Aleksandr O. Chubarian, Ilia V. Gaiduk, and Nataliia I. Egorova (Moscow: Institut vseobshchei istorii RAN, 1998), pp. 291-314; and idem, "Soviet Perceptions of the Formation of NATO, 19481953," paper presented at the Norwegian Nobel Institute, Oslo, March 1998.

2 Vojtech Mastny, “The Soviet Union and the Origins of the Warsaw Pact in 1955," in Mechanisms of Power and Soviet Union, ed. Niels Erik Rosenfeldt, Bendt Jensen, Erik Kulavig (Houndmills, Basingstoke: Macmillan, 2000), pp. 241-266. accession by additional countries - made easier in the Warsaw than the NATO document. ${ }^{3}$

The dissimilarities concerned matters of less practical importance but more revealing of the Warsaw treaty's main purposes. Unlike NATO's commitment to uphold the common values and institutions of its members, the Soviet-made alliance merely affirmed such platitudes as the promotion of peace and friendship, besides advancement of economic and cultural relations. More to the point, the Warsaw document dwelt on the desirability of establishing in Europe a collective security system, reducing armaments, and banning weapons of mass destructionall leitmotifs of Soviet diplomacy at the time. Yet, apart from the proclamation of the new alliance, hardly anything was done to build it up - as NATO had so feverishly tried to do at the time of its creation before.

By modeling the Warsaw Pact on NATO but not proceeding to give it substance, Khrushchev would find it that much easier to discard what Western officials rightly perceived as a "cardboard castle" 4 if, by doing so, he could attain their consent to its replacement by the collective security system he wanted. Following on the dissolution of the phantom Eastern alliance along with the real Western one while leaving Moscow's network of bilateral military treaties with its dependencies intact, such a system would have allowed the Soviet Union as its strongest member to become the arbiter of European security.

It is hardly surprising that NATO did not take the project seriously; what is surprising is that its Soviet architects apparently thought their Western counterparts might. The documents they prepared anticipated

3 The respective texts, often reprinted, can be found, for example, in NATO: Basic Documents (Brussels: NATO Information Service, 1989), pp. 10-13, and Documents on International Affairs 1955, ed. Noble Frankland (London: Oxford University Press, 1958), pp. 193-97.

4 Quoted in Robert Spencer, "Alliance Perceptions of the Soviet Threat, 1950-1988," in The Changing Western Analysis of the Soviet Threat, ed. Carl-Christoph Schweitzer (London: Pinter, 1990), pp. 9-48, at p. 19. 
negotiations. ${ }^{5}$ Khrushchev acted as if he had believed his Western adversaries could somehow be maneuvered into a situation in which they would see no choice but to acquiesce in his proposals even against their better judgment. A true believer in the Soviet system's ability to outperform its capitalist rival because of the former's presumably irresistible ascendancy in the nonmilitary attributes of power, he was sufficiently confident that he could rely less on the military ones. Hence, no sooner was the Warsaw Pact created than he proceeded with unilateral reductions of both Soviet and East European conventional forces. ${ }^{6}$

As Moscow's design for the dissolution of both alliances faltered, the Warsaw Pact came to stay by default. Without any more incentives to make it into a military counterpart of NATO, Khrushchev continued to use it mainly as a conduit for launching further diplomatic initiatives. Its political consultative committee (PCC), established in 1956 as a façade for occasional convocations of Eastern Europe's party chiefs under Soviet auspices, did not become an equivalent of the North Atlantic Council - with its semiannual policymaking conferences of the heads of state or foreign ministers, supplemented by the permanent representatives of the signatory governments meeting in continuous session. The PCC's proclaimed intention to furnish the alliance with additional institutions, particularly a secretariat and a committee of foreign ministers, remained unfulfilled. ${ }^{7}$

Separately a supreme command was set up and given to a Soviet marshal, equipped with arbitrary powers loosely described in a document

5 Soviet draft of "General European Treaty on Collective Security in Europe," 20 July 1955, FRUS, 1955-57, vol. 7, pp. 516-19; Soviet proposal of draft treaty on security in Europe, 31 October 1955, Frankland, Documents on International Affairs 1955 , pp. 53-55.

6 Khrushchev to Bierut, 12 August 1955, KC PZPR 2661/3, AAN; Matthew Evangelista, "Why Keep Such an Army?”: Khrushchev's Troop Reductions. Cold War International History Project Working Paper 19 (Washington: Woodrow Wilson International Center for Scholars, 1997).

7 Stenographical record of the PPC meeting in Prague, 27-28 January 1956, 775/1/1/1, AVPRF. appropriately kept secret. ${ }^{8}$ Imposed without even a pretense of consultation and designed mainly for the conveyance of orders from Moscow to the Eastern European capitals, the system was a caricature rather than a replica of SHAPE and SACEUR. Moreover, it remained secondary to the system of Soviet "advisers," on whom Moscow continued to rely for the control of its vassal armies. Sometimes Soviet officers were installed outright in key command positions - such as was Poland's minister of defense, Marshal Konstantin K. Rokossovskii, masquerading as a Pole.

The original creation of the Warsaw Pact as a mirror image of NATO nevertheless came to haunt the Kremlin once Eastern Europe erupted in revolt in 1956. Chafing under humiliating Soviet tutelage, reformminded Polish generals attempted to transform the lopsided alliance into one more resembling a partnership of equals. An outspoken memorandum by deputy chief of staff Gen. Jan Drzewiecki chided the prerogatives of the Soviet supreme commander as incompatible with Polish independence and sovereignty. It found the "purely formal" representation of the lesser allies on his staff unacceptable. ${ }^{9}$

Drzewiecki did not mince words in describing Moscow's offhanded manner in dictating to Poland how to build its army and he even cast doubt on the legality of the procedures used to establish the Warsaw Pact in the first place. But neither he nor his colleagues questioned the necessity of the Soviet alliance as a safeguard against what they, along with most Poles, regarded as an enduring German danger. Accepting the presence of Soviet troops on their territory as unavoidable if painful, they tried to mitigate the pain by alluding as an example to the status of US forces in different foreign countries. And even though the example was never followed, at least Poland managed to negotiate a

8 "Statute of the Unified Command of the Member States of the Warsaw Treaty" 7 September 1955, Vojtech Mastny, “'We Are in a Bind': Polish and Czechoslovak Attempts at Reforming the Warsaw Pact, 1956-1969" Cold War International History Project Bulletin 11 (1998): 230-50, at pp. 235-36.

9 "Memorandum on the Warsaw Treaty and the Development of the Armed Forces of the People's Republic of Poland," 10 January 1957, ibid., pp. 236-38. 
more favorable status-of-forces agreement with Moscow than any other of its allies. ${ }^{10}$

The attempted reform of the alliance, however, was scuttled. When the new Polish defense minister, Marian Spychałski, raised the issue with supreme commander Marshal Ivan S. Konev, the marshal was offended at the suggestion that his office might be filled by rotation. "What do you imagine," he exploded, "that we will make some NATO here?"11 Later on, when reasserting control over the Polish military, Moscow preferred to bypass the Warsaw Pact, relying instead on party channels and counterintelligence services, still headed by a Soviet officer. ${ }^{12}$

Khrushchev's brinkmanship during the confrontation he started in 1958 over Berlin exposed the East Europeans to unprecedented risks. At the peak of the crisis in 1961, Konev's successor Andrei A. Grechko ordered them to mobilize in case the separate peace treaty Moscow intended to sign with East Germany would provoke military action by the Western powers to assert their rights in Berlin. ${ }^{13}$ And although Khrushchev subsequently decided not to sign the treaty, his willingness to risk such a conflict had momentous consequences for the Warsaw Pact's strategic posture. A later report by the Czechoslovak ministry of defense retrospectively described what had happened:

The former strategic concept, which gave our armed forces the task to "firmly cover the state border, not allow penetration of our territory by enemy forces, and create conditions for active operations of other allied forces," was changed without discussion in the Political Consultative

10 Commentary by Drzewiecki, undated [November-December 1956], KC PZPR 2661/124, AAN; Tadeusz Pióro, Armja ze skaz: W Wojsku Polskim 1945-1968 (wspomnienia i refleksje) [The Defective Army: In the Polish Army, 1945-1968 (Memories and Reflections)] (Warsaw: Czytelnik), 1994, pp. 277-80.

11 Ibid., pp. 280-82.

12 Andrzej Albert, Najnowsza historia Polski, 1918-1980 [Poland's Contemporary History] (London: Puls, 1991), pp. 805-806.

13 Record of the East German National Defense Council meeting, 28 August 1961 DVW1/39464, BA-MA; resolutions of the Czechoslovak party Military Commission on Defense, 2 September 1961, VKO 18/4, VHA
Committee, and the Czechoslovak People's Army was assigned an active task. $^{14}$

The perils of the "active task" became clearer once the alliance's Soviet supervisors began to draw detailed plans for a deep thrust deep into Western Europe, involving massive use of nuclear weapons by both sides, and to conduct "realistic" exercises to simulate it. The scenario was certain to devastate, if not annihilate, the Warsaw Pact's Central European nations, though not nearly to the same extent the Soviet Union. A similar predicament preoccupied America's Western European allies, so it was especially to them that Poland's savvy foreign minister Adam Rapacki addressed his successive plans for a nuclear-free zone in Central Europe. ${ }^{15} \mathrm{He}$ sought to diminish the likelihood of the holocaust by putting restraints on both superpowers. In his novel variant of the NATO model, successful pressure on Washington by its allies was to make the Soviets similarly responsive to theirs.

At the time of the 1962 Cuban missile crisis, however, it was only after the confrontation had passed that Khrushchev saw fit to brief the stunned Eastern European leaders that the outbreak of war had only been "a few minutes away." 16 They had additional reasons to worry about being dragged by Moscow into its conflict with China. Romania

14 "Materiály k otázce Spojeného velení," [Materials Concerning the Issue of Unified Command], undated [early 1966], GŠ-OS 0039042/1, AMO.

15 Piotr S. Wandycz "Adam Rapacki and the Search for European Security" in The Diplomats, 1939-1979, ed. Gordon A. Craig and Francis L. Loewenheim (Princeton: Princeton University Press, 1994), pp. 289-317, at pp. 299-307. Cf. Teresa Lós-Nowak, "Geneza planu Rapackiego utworzenia strefy bezatomowej w Ewropie środkowej: źrodła motywacyjne, podstawowe założenia i cele," [The Genesis of Rapacki's Plan of Nuclear-Free Zone in Central Europe: Motives, Principles, and Goals], in Plan Rapackiego a Bezpieczeństwo Europejskie [The Rapacki Plan and European Security] (Wrocław: Wydawnictwo Uniwersytetu Wrocławskiego, 1991), and idem, Polskie inicjatywy w sprawie broni nuklearnej $w$ Europie środkowej, 1957-1964 [Polish Initiatives Concerning Nuclear Weapons in Central Europe, 1957-1964] (Wrocław: Wydawnictwo Uniwersytetu Wrocławskiego, 1989).

16 Report by Novotný to Czechoslovak party central committee, 2 November 1962, ÚV KSČ 01/98/85, SÚA. 
responded by secretly assuring the US government that in case of a nuclear confrontation between the two superpowers it would remain neutral. ${ }^{17}$ And, when Khrushchev surreptitiously tried to expand the applicability of the Warsaw Pact beyond Europe by backing Mongolia's bid for admission, Rapacki used all his skills of persuasion to successfully fend it off. ${ }^{18}$

NATO's Multilateral Force (MLF) project of 1963, with its prospect of letting West Germany share nuclear weapons, proved the catalyst of discord not only in the Western but also the Eastern alliance. At issue in the wrangling within the Warsaw Pact was the question of how best to block the MLF while also preventing further nuclear proliferation, notably the acquisition of the bomb by China. The convoluted dispute pitted the "northern tier" countries still fearful of the German threat and the "southern tier" ones more disposed to regard Bonn as a potentially beneficial trading partner-with Moscow temporarily vacillating between assigning higher priority to Germany or China. ${ }^{19}$

Khrushchev's fall from power in 1964, China's first nuclear test in the following year, and the concurrent eclipse of the MLF sorted out the issue, but the Warsaw Pact's solidarity in dealing with NATO suffered irreparable damage. When the PCC reconvened in January 1965 after an eighteen-month interval, Poland's leader Władysław Gomułka retrospectively censured Khrushchev's habit of not consulting with members of the alliance. ${ }^{20}$ The East German chief Walter Ulbricht, the initiator of the meeting, proposed that their foreign ministers meet regularly-as their Western counterparts had been doing. And

17 Raymond L. Garthoff, "When and Why Romania Distanced Itself from the Warsaw Pact," Cold War International History Project Bulletin 5 (1995): 111. Cf Mircea Suciu, "Criza rachetelor din Cuba și apropierea româno-americană" [The Cuban Missile Crisis and the Romanian-American Rapprochement], Dosarele istoriei [Bucharest], 1997, no. 6: 30-31.

18 Khrushchev to Gomułka, 10 July, Cedenbal to Cyrankiewicz, 15 July, and memorandum by Rapacki, 20 July 1963, KC PZPR 2662/521-30, AAN.

19 Douglas E. Selvage, "Poland, the German Democratic Republic and the German Question, 1955-1967,' unpublished Ph.D. diss., Yale University, 1998, pp. 120-50.

20 Minutes of the PCC meeting in Warsaw, 20 January 1965, KC PZPR 2662/159-90, at p. 189, AAN.
Hungary's János Kádár expressed regrets that in the UN not only the NATO ministers but also the Asian and African ones meet for mutual consultations but the Soviet Union and its allies do not. Khrushchev's successor Leonid I. Brezhnev concurred that "we need to give an expression to our unity and striving for more concerted work." 21

But the Romanian premier Ion Gheorghe Maurer retorted that "we are for consultation but against the creation of any organs," such as a committee of foreign ministers obliged to meet regularly. Taking exception to Moscow's practice of submitting to the allies ready-made proposals at short notice in the expectation of quick approval, the Bucharest party boss Gheorghe Gheorghiu-Dej further questioned Brezhnev's demand to respond to NATO's plans by military countermeasures rather by promotion of détente. ${ }^{22} \mathrm{He}$ appropriated to himself Khrushchev's original idea of a simultaneous dissolution of both military blocs, which henceforth became a Romanian staple. The PCC disbanded without accomplishing anything.

The contentious gathering set the tone for the years to come, when Romanian dissidence came into the open while the more subtle and consequential issue of reform, championed particularly by the Poles, remained largely out of sight. Unlike Poland's communists, who wanted expanded room for action for their country to influence Soviet policy in a strengthened Warsaw Pact, the Romanian ruling clique aimed at maximum freedom of action for itself by minimizing Moscow's role in a weakened alliance, or perhaps its abolition. For the Soviet Union, the challenge was to so reform the alliance that dissent within it could be contained and, as in NATO, made a proof of its strength rather than a source of weakness.

The April 1965 conference of economic planners of the military grouping revealed fundamental disagreements about what, if anything, should be done to prepare it for war already in peacetime. ${ }^{23}$ In the same

21 Ibid., p. 184-90.

22 Speech by Gheorghiu-Dej at the PCC meeting in Warsaw, 19 January 1965, ZPA, J IV 2/202-256 Bd 8, SAPMO.

23 Report on the 9-15 April 1965 conference, undated, VKO 31/10, VHA. 
month, the attempted coup by Bulgarian officers against their country's leaders, famously obsequious to Moscow, provided the spectacle of the Warsaw Pact's first and only military rebellion. Now it was the Soviet

Union itself, rather than its disgruntled dependents, that took the initiative in trying to reform and invigorate the alliance.

In striving for a more effective counterpart, though by no means a replica, of NATO, Moscow proved its willingness to learn. When Brezhnev, in January 1966, wrote to the party chiefs of Eastern Europe to propose developing the alliance's structure and improving its way of operation, he did so after duly consulting with them in advance. ${ }^{24} \mathrm{He}$ invited their input rather than merely telling them what he wanted them to do. He none the less expected the reorganization to be finished in two months; it would take an eventful three years. 


\section{The Reform of the Warsaw Pact (1966-69)}

In setting the stage for the Warsaw Pact's reform, the concurrent crisis of NATO was crucial. Not only did the MLF fail to get off the ground, but the Western alliance also became mired in disputes about the wisdom of introducing the US-promoted strategy of flexible response, which proposed to widen the range of fighting options by lifting the threshold between conventional and nuclear war. To its European critics, whose greater concern was about the threshold between war and peace, the strategy portended the increased likelihood of their countries becoming a battlefield precisely at a time when the prospects of détente appeared brighter. Warsaw Pact assessments found the discord within the enemy camp reassuring:

It is to be considered most likely that during the next five to ten years the military potential of NATO will not experience any such radical changes that would materially alter the current basic assumptions about the role of the threat of force in NATO's policy. . . . The reasons rendering deliberate initiation of a general nuclear war by the West improbable during the next several years include its unresolved problem of anti-nuclear defense, . . . disagreements within NATO, especially the development of France's attitude toward the United States and the alliance in its present form, and the deepening US involvement in Vietnam. ${ }^{25}$

With NATO in disarray, Moscow could thus better afford to consider concessions to its own restive allies while also accommodating Soviet generals bent on making the Warsaw Pact a more effective instrument of war rather than mere framework for diplomacy and bloc management. Advancing its "militarization" ever since the 1961 climax of the Berlin crisis had provided a justification, the Soviet military, too, had

25 “Komplexní plán výstavby ČSLA na léta 1966-1970" [The Comprehensive Plan for the Development of the Czechoslovak People's Army in 1966-1970], 26 April 1966, prepared for the session of the Military Commission for Defense, 5 May 1966 , VKO 34/11, VHA been interested in expanding the range of their fighting options even before the issue became critical for NATO. And Brezhnev who, unlike Khrushchev, was a champion and favorite of the generals, was more responsive to their entreaties.

Heeding the allies' sensibilities, Moscow proposed to clarify the powers of the supreme commander and his staff in peacetime while leaving the extent of his authority in wartime unspecified as not immediately topical. It did not envisage, however, altering the "well-established practices," 26 targeted by Poland's reform-minded generals as early as 1956 and now obviously irritating to other allies as well. The Soviet proposals called for the creation of a "military council" as the PCC's subsidiary in charge of military matters and a committee on technology to supervise research and development in a more systematic and efficient fashion than had so far been possible through the widely resented directives from Moscow. The thrust of the proposals was thus toward creating new institutions rather than making any radical change in the functioning of the already existing ones.

A juxtaposition of the proposed institutions with their NATO counterparts shows the limits of what Moscow was willing to tolerate. As in NATO, the prospective military council was to be an extended arm of the alliance's supreme political body. But there was a difference in kind between the two; the North Atlantic Council was a well-established decision-making body representative of the member nations while the Soviet-run PCC was aptly described by Rapacki as amounting to "sporadic summit meetings, usually ill-prepared and given to adopting rather spectacular resolutions." 27 There was another telling distinction between NATO's crucial Military Committee, acting for the member nations through their chiefs of staff, and the council envisaged by Moscow, which was to augment the alliance's Soviet-controlled command with the defense ministers of its signatory states acting in no more than an advisory role, thus creating an appearance of participation without real substance.

26 Report on the 4-9 February 1966 meeting of chiefs of staff in Moscow, undated [February 1966], GS-OS 1966, 0039042/24, p. 2, AMO; texts of Soviet proposals, VA-01/40404, pp. 127-41, BA-MA, and ZPA J IV 2/202-259 Bd 11, SAPMO.

27 Memorandum by Rapacki, 21 January 1966, KC PZPR 2948/48-53, at p. 49, AAN. 
At the beginning of February, Grechko submitted the draft statutes of the Warsaw Pact's future military institutions for expeditious approval by a Moscow meeting of chiefs of staff. Then, at the Berlin conference of deputy foreign ministers that immediately followed, Soviet representative Leonid F. Ilichev presented analogous statutes of the PCC as well the prospective committee of foreign ministers and permanent secretariat. Intended to coordinate foreign policy, the former was to approximate one of the functions of the North Atlantic Council, while the latter was to fill an important void that had distinguished the Warsaw Pact from its Western rival. ${ }^{28}$

Far from sailing through as easily as had been expected, however, the proposals were stalled as both meetings ended without an agreement on anything, even on further discussion. The attempt to consolidate the alliance prompted the Romanians to question its fundamental premises, particularly the subordination of its national armed forces to the will and whim of the Soviet supreme commander. None of the other allies went so far in articulating goals and priorities different from Moscow's. They did not want, nor could they hope, to make the Warsaw Pact into another NATO, yet in their own ways they tried to remake it so they would be able to question the crude and overbearing Soviet domination much as NATO's junior partners were able to question the more subtle and less pervasive American domination.

As in NATO, control over nuclear weapons became the apple of contention in the Warsaw Pact once the arms race began to appear to be getting out of hand. Recalling the Cuban missile crisis, Romania's chief of staff Gen. Ion Gheorghe stated bluntly that Moscow's failure to consult the allies had threatened to put them into "a situation that would lead them to a state of war, without their own countries' parties and governments as the supreme organs of state power being able to make the appropriate decisions about it." 29 Even Czechoslovak officials,

28 Records of the Moscow meeting of chiefs of staff, 4-9 February 1966, VA-01/40404 pp. 88-126, and VA-01/40413, pp. 45-82, BA-BA; records of the Berlin meeting of deputy foreign ministers, 10-12 February 1966, ZPA J IV 2/202-257 Bd 9, SAPMO.

29 Excerpts from the statement by Gheorghe at the meeting of the Warsaw Pact chiefs of staff, 4-9 February 1966, GŠ-OS 1966, 0039042/15, p. 5, AMO. otherwise noted for their complaisance, took exception to Moscow's making decisions about the development of their armed forces without keeping them informed about its intentions. ${ }^{30}$ Ominously, an agreement concluded the preceding December allowed for the stationing of Soviet nuclear warheads on missiles at three Czechoslovak sites, thus altering the previous practice of keeping the ordonance outside of the country unless needed in an emergency. ${ }^{31}$

Striving to inhibit the use by the Soviet Union of its nuclear weaponry was the common denominator of diverse responses to its reform program. The Czechoslovaks wanted the proposed military council to function as a subcommittee of the PCC that would ensure common strategy and appropriate military planning - much as NATO's Military Committee had been doing. 32 Without illusions that this could work, the Romanians sought instead a committee capable of tying the hands of the Soviet supreme commander by giving each of its members the right of veto. ${ }^{33}$ Unable to find support for the idea, the Romanian deputy foreign minister Mircea Malița stood pat, pleading the lack of authority to agree to anything. Marian Naszkowski, his colleague from Poland, got it right that Bucharest wished to have no additional ties with the Warsaw Pact while loosening the ones it had, aiming at nothing less than "to paralyze the alliance and transform its organs into noncommittal discussion clubs." 34

30 "Příklady neupřesnění nebo nedořešení otázek se Spojeným velením" [Examples of Unclarified or Unresolved Questions Regarding the Unified Command], undated [January 1966], GŠ-OS 1966, 0039042/10, AMO.

31 Antonín Benčík, Operace "Dunaj”: Vojáci a Pražské jaro 1968: Studie a dokumenty [Operation 'Danube': The Military and the 1968 Prague Spring: Studies and Documents] (Prague: Ústav pro soudobé dějiny AV ČR, 1994), p. 17.

32 "Opatření k upevnění Varšavské smlouvy v oblasti vojenské" [Proposed Measures for the Military Strengthening of the Warsaw Treaty], undated [January 1966], GŠOS 1966, 0039042/59, AMO.

33 "Vojenská poradní rada" [The military Advisory Council], undated [February 1966], GŠ-OS 1966, 0039042/64, AMO.

34 Naszkowski to Rapacki, 17 February 1966, KC PZPR 2948, pp. 58-69, at p. 68, AAN 
It was the Poles who took the lead in defending the Soviet alliance against Romanian obstruction while trying to bolster it by applying some of the key features of NATO. Rapacki wanted to create a true policymaking body analogous to the North Atlantic Council, while limiting the PCC to the consultative role its name presumably suggested. So the latter would in effect become the council of foreign ministers that Moscow also wanted. Responding to Soviet proposal for a permanent secretariat, Rapacki wanted it to be substantive, "set up at a proper level and with a proper composition"-namely, genuinely representative of the member states and capable of preparing the agenda for the Council's meetings, in short, much like the NATO secretariat. He thought it should be headed by a political figure of high standingunlike the supreme commander not necessarily a Soviet citizen and in any case someone "disconnected from state functions in his own country." This would not have left room for respected politicians from the smaller countries like himself - or like most of the general secretaries of NATO. In order to "emphasize the political vitality of the Warsaw Pact," Rapacki concluded in a thoughtful memorandum, "the new measures . . . should be made public." 35

The Polish ministry of defense complemented Rapacki with its own ideas on military matters. Without casting a doubt on the desirability of the alliance and the necessity of Moscow's leading role, it envisaged changes in the structure and functioning of its command that the Soviet Union could be expected to countenance. With it rather than against it the Poles argued that "the position of the general staff of the Unified Armed Forces as a command organ in wartime is still a matter too premature to be considered." They supported Moscow's concept of a military council, supplementing it with an advisory committee of defense ministers reminiscent of NATO's Defense Planning Committee. The committee would put on a regular footing the already existing practice of the ministers' holding periodic gatherings. Poland's military sought more input into decisions about the development of the country's armed forces while specifically excluding the Soviet-owned nuclear weapons from purview by members of the alliance if only a way could

35 Memorandum by Rapacki, 21 January 1966, Mastny, “'We Are in a Bind”, pp. 23638. be found to "define an obligatory scope and method for use of the strategic assault forces for the common defense of the Pact members." 36

Instead of demanding access to those doomsday weapons-something that Moscow was certain not to allow anyway -37 the Poles sought to induce such changes in the international environment that would inhibit the weapons being used in the first place, while also making Moscow's inevitable military supremacy less onerous in practice. This was the gist of Rapacki's diplomacy, which was congenial to West Europeans worried about superpower domination but otherwise loyal to NATO-such as its former secretary general and current foreign minister of Belgium, Paul-Henri Spaak. Rapacki went to Brussels to solicit his support after proposing to the UN the convocation of a European security conference including the United States. ${ }^{38}$ A prominent item on its agenda was to be banning further deployment of nuclear weapons in Europe-which, among the Warsaw Pact countries, East Germany, Czechoslovakia, and Hungary, but not Poland, had already consented to be installed on their territories. ${ }^{39}$

Once the Moscow meeting of the chiefs of staff ended inconclusively, the Polish regime of the increasingly conservative Gomulka-who had pointedly criticized Rapacki for excessive independence- 40 chose not to present most of his reform ideas to the subsequent Berlin conference.

36 Memorandum by the Polish Ministry of National Defense, 26 January 1966, ibid., pp. 241-43.

37 Speculations that Moscow was at any time willing to, or that its allies ever wanted, a "dual key" arrangement comparable to NATO's have so far not been substantiated by evidence. See Mark Kramer, "The 'Lessons' of the Cuban Missile Crisis for ated by evidence. See Mark Kramer, "The 'Lessons' of the Cuban Missile Crisis for
Warsaw Pact Nuclear Operations," Cold War International History Project Bulletin 5 (1995): 59, 110-15, 160, at pp. 112-14.

38 Selvage, "Poland, the German Democratic Republic and the German Question," pp. $157-59,172$

39 The weapons were later surreptitiously deployed on Soviet bases in Poland without the consent of its government. Pióro, Armja ze skaza, pp. 279-80.

40 Minutes of the PCC meeting in Warsaw, 20 January 1965, KC PZPR 2662/152-90, at p. $187, \mathrm{AAN}$ 
Instead Naszkowski provided there Polish backing to the Soviet plans for the secretariat and foreign ministers committee, where policies could at least be discussed if not decided, and pursued only such amendments to the document about supreme command that were known to be in line with Soviet thinking. ${ }^{41}$ Nor did the Czechoslovaks air their demand for a substantive change in the functioning of the command that they had included in their preparatory papers. ${ }^{42}$

With decisive help from the Poles, the Soviet Union could then proceed with its program. After Grechko's consultations in Warsaw, it endorsed their amendments that would leave the national armed forces under the command of their governments as long as there was no war, have the supreme commander make recommendations rather than issue directives, and would give the allies a say in the development of their military as well as the determination of their financial contributions to the common cause. All this was still a far cry from NATO's way of operating, but it was an important step forward toward mollifying their grievances. In May 1966, the conference of defense ministers in Moscow agreed to the texts of the statutes for the joint command and committee on technology, and forwarded them to the PCC for final approval. ${ }^{43}$

This approval, however, hinged on the reservations attached by Romania to the first, though not the second document. ${ }^{44}$ Moreover, Bucharest leaked rumors about being opposed to the reform plan in principle and went public pleading for the abolition of both military groupings, the dismantlement in Europe of all foreign bases, and the withdrawal from there of all foreign troops-demands more disruptive

41 Memorandum by Naszkowski, 31 May 1966, KC PZPR 2948, pp. 54-57, AAN.

42 "Materiály k otázce Spojeného velení" [Materials Concerning the Question of Unified Command], GŚ-OS 1966, 0039042/1, AMO.

43 "Notatka w sprawie wyników konferencji ministrów obrony państw-uczestników Układu Warszawskiego" [Note on the Results of the Conference of Defense Ministers of the Member States of the Warsaw Treaty], and texts of the statutes, KC PZPR 2663, pp. 234-47, AAN.

44 “Osoboe mnenie" [Dissenting View], 28 May 1966, VA-01/40390, p. 20, BA-MA of the Warsaw Pact than of NATO.45 Considering that the Romanian challenge to the integrity of the Soviet alliance was more fundamental than any NATO ever faced, Moscow's forbearance of the mischief was extraordinary.

Rather than pressing for the acceptance of the reform plans, Moscow tried to rally its allies on other divisive issues-relations with West Germany, the conflict with China, the Vietnam War. Those issues dominated the agenda of both the June conference of foreign ministers in Moscow and the meeting of the party chiefs in Bucharest the following month, where acrimonious exchanges erupted between the Romanian leader, Nicolae Ceaușescu, and Soviet loyalists. ${ }^{46}$ While Poland, together with East Germany, again tried to defend the integrity of the Warsaw Pact against the Romanians, Moscow preferred to mediate to prevent a break. "One must be patient," Brezhnev explained to Ulbricht, for "comrade Ceaușescu is still young and inexperienced."47

At Bucharest, the Soviet Union struck an informal deal by shelving the Warsaw Pact's reorganization in return for its members' support of a conference on European security - the originally Polish idea Moscow now adapted to its own purposes. Rather than striving to mitigate conflict between the superpowers through rapprochement between their junior partners, the Soviet version of the proposal was designed to drive a wedge within NATO by excluding the United States. Commenting upon the outcome of the Bucharest meeting, Brezhnev noted with satisfaction that, "with less lecturing and shouting about friendship," relations within the communist alliance had turned for the better. ${ }^{48}$

45 Fritz Ermarth, Internationalism, Security, and Legitimacy: The Challenge to Soviet Interests in East Europe, 1964-1968 (Santa Monica: RAND, 1969), p. 36.

46 Records of the Moscow conference of foreign ministers, 6-17 June 1966, and the Bucharest meeting of the party chiefs, 5-7 July 1966, ZPA J IV 2/202-258 Bd 10, SAPMO, and KC PZPR 2663, pp. 281-315, AAN.

47 Record of Brezhnev-Ulbricht conversation, 9 October 1966, ZPA J IV 2/202/344 Bd 10, SAPMO.

48 Ibid. 
Shortly before this happened, France's President Charles de Gaulle, having already served notice of his country's intention to leave NATO's integrated command, had gratified the Kremlin leaders by signaling to them a readiness to negotiate about European security without the Americans. During his visit to Moscow before the Bucharest conference, he had told them of his desire to achieve the withdrawal of US troops from Europe and the recognition of its post-World War II boundaries "in the broadest sense of the word." 49 Although the Soviets were wary of him - not the least because of the bad example France's action toward NATO might give not only Romania but also other Warsaw Pact allies - they had nevertheless been encouraged in their campaign for the security conference. .0

A year and a half later, however, the campaign had still led nowhere, while France's severance of its ties with NATO proved not nearly as damaging as might have been expected. In fact, it allowed the alliance to lay to rest its principal disagreements, and proceed toward the adoption of the flexible response strategy the French had been opposing. ${ }^{51}$ And, by proclaiming its new posture of defense cum détente in its landmark Harmel Report at its December 1967 ministerial meeting, a reinvigorated NATO challenged the Warsaw Pact for a nonmilitary competition just as its own integrity was about to unravel in the coming Czechoslovak crisis.

The crisis terminated Moscow's appeasement of Romania while giving the impetus to reviving the dormant project for the reorganization of the alliance. In February 1968, its new commander Marshal Ivan I. Iakubovskii urged its chiefs of staff to tackle without further delay the pending proposal for a military council. The Romanians had been

49 Statement by Brezhnev at the Bucharest meeting of the PCC, 7 July 1966, KC PZPR, 2663, p. 310, AAN.

50 Keith A. Dunn, Soviet Perceptions of NATO (Carlisle Barracks: U.S. Army War College, 1978), pp. 7-8; Mikhail Narinski, "Les soviétiques et la decision française,' in France et l'OTAN, 1949-1996, ed. Maurice Vaïsse, Pierre Mélandri, and Frédéric Bozo (Brussels: Complexe, 1996), pp. 503-16.

51 Helga Haftendorn, NATO and the Nuclear Revolution: A Crisis of Credibility, 1966-1967 (Oxford: Clarendon Press, 1996), pp. 320-85. trying to revise it by requiring the prospective council to act by unanimity, thus preventing its becoming a tool of the supreme commander. Iakubovskii insidiously suggested that the time was ripe for an agreement since they had allegedly dropped this requirement. ${ }^{52}$ When they protested that they had not, Moscow took the position that Romania need not take part in the deliberations of the Warsaw Pact's highest military councils or consider itself bound by those of their decisions that it did not approve- a formula originally advocated by East Germany as early as two years ago. ${ }^{53}$

This was a radical departure from the previous management of the alliance though otherwise a reconfirmation of a trend that had been underway ever since its birth. At issue was the differentiation between its strategically crucial "northern tier" and the relatively insignificant southeastern flank. ${ }^{54}$ The differences set apart the three conservative northern regimes, two of which vied with each other for Moscow's recognition as its premier ally while Czechoslovakia had so far gone along, making the remaining allies less indispensable.

By then, it had also become clear that France's self-exclusion not only did not impair NATO's viability but in fact improved it. The lesson was not lost on Moscow as it was positioning itself for a crackdown against Czechoslovakia under the guise of a Warsaw Pact collective action which the Romanians strenuously opposed. France unwittingly showed the Soviet Union how a recalcitrant ally could be effectively neutralized. In his new capacity as Soviet defense minister, Grechko could

52 "Notatka o wynikach narady szefów sztabów generalnych armii państw-cłonków Układu Warszawskiego" [Note on the Results of the Conference of the Chiefs of Staff of the Member States of the Warsaw Treaty], 19 February-1 March 1968, KC PZPR 2663, pp. 366-80, AAN

53 Report by Naszkowski on the Berlin conference of deputy foreign ministers, 17 February 1966, KC PZPR 2948, pp. 64-69, AAN.

54 Beate Ihme-Tuchel, Das "nördliche Dreieck": Die Beziehungen zwischen der DDR, der Tschechoslowakei und Polen in den Jahren 1954 bis 1962 (Cologne: Wissenschaft und Politik, 1994), pp. 64-68, 360-78 
then reassure his politburo superiors that the alliance could continue functioning without Romanian participation. ${ }^{55}$

The Soviet Union moved toward completing the reorganization simultaneously while the Czechoslovak crisis was mounting. In March, the PCC agreed to submit the new statutes to the defense ministers, and have them ready for final approval within six months. Iakubovski toured all the allied capitals, Bucharest excepted, to iron out the remaining differences. He met with a constructive response everywhere but Hungary, whose government procrastinated by invoking the greater need to prevent a break with Romania. ${ }^{56}$

Czechoslovakia's communist reformers did not threaten the Warsaw Pact's military cohesion as much as the country's political upheaval seemed to suggest. Its increasingly free press questioned rhetorically the reliability of Moscow's nuclear umbrella, implying that Czechoslovakia might take a cue from France's example in going its own way. ${ }^{57}$ But the party chief Alexander Dubček reassured the anxious members of the PCC that "our security has already now been effectively guaranteed by the nuclear power of the USSR." 58 The Prague party leadership and especially the top military went out of their way to dissociate themselves from the critique of Soviet alliance management expressed by their subordinates. And although Moscow, in looking for a pretext to intervene, alleged a NATO conspiracy to snatch

55 Rudolf G. Pikhoia, "Chekhoslovakiia, 1968 god, vzgliad iz Moskvy: Po dokumentam TsK KPSS" [Czechoslovakia 1998: The View from Moscow after Document of the Central Committee of the CPSU], Novaia i noveishaia istoriia, 1994, no. 6: 3 20 , at p. 8.

56 Minute of Iakubovskii-Gomułka meeting, 19 April 1966, KC PZPR 2663, pp. 412 17, AAN; reports on Iakubovskii's visit in the GDR on 20-21 April 1966, VA01/40391, pp. 116-23, and DVW1/39489, BA-MA; report on Iakubovskii-Dzúr conversation, 24-25 April 1966, GS-OS 1968, 0039042/77, AMO; record of conversation at Czechoslovak general staff with Col. Fazekás, 25 June 1966, GŠ-OS 1968 0036049/3, AMO

57 Condoleezza Rice, The Soviet Union and the Czechoslovak Army, 1948-1983: Uncertain Allegiance (Princeton: Princeton University Press, 1984), p. 102.

58 Speech by Dubček at the Sofia meeting of the PCC, 6 March 1968, AÚV KSČ 02/1/4011/26, SÚA.
Czechoslovakia away from the Warsaw Pact, the Prague reformers in fact never demanded anything more specific than greater voice in its councils. Unlike the Poles on earlier occasions, they did not invoke the NATO model but rather the damage inflicted on the economy by excessive militarization.

By then, the Kremlin leaders had themselves realized that the alliance needed to be reformed by giving its members more of a sense of belonging, although Soviet generals found it difficult to abandon their bossy habits. Having observed their boorishness during the exercises staged to rehearse the invasion of Czechoslovakia, Polish general Tadeusz Tuczapski lamented how intolerable the "shortcomings, imprecisions, and unfinished sections" of the Warsaw treaty had become, threatening "to sooner or later lead to the decline of the Soviet Union's credibility and the weakening of the alliance."59 Yet once successfully accomplished, the invasion actually helped strengthen the alliance as a Soviet tool, facilitating the completion of the reform as Moscow desired.

Having already been drafted and provisionally approved by all the members except Romania before the August 1968 invasion, the key documents were afterwards reluctantly accepted by the isolated Romanians with but minor changes. ${ }^{60}$ Bucharest remained understandably uneasy about the provision authorizing the supreme commander to deploy troops on the alliance's territory even in peacetime. ${ }^{61}$ But at the PCC's Budapest meeting in March 1969, the new statutes were sealed without further discussion; the persisting severe disagreements pertained to other issues, particularly the projected European security

59 "Notatka slużbowa dotyczaca ćwiczenia operacyjno-strategicznego 'SZUMAWA", [Service Note on the Strategic Operational Exercise 'Sumava'] undated [July 1968], KC PZPR 2663, pp. 419-24, at p. 207, AAN.

60 Record of the Moscow meeting of deputy chiefs of staff, 12-17 September 1968, KC PZPR 2663, pp. 431-88, AAN.

61 Record of the Moscow meeting of defense ministers, 29-30 October 1968, VA01/40405, pp. 6-47; Iakubovskii to Jaruzelski, 6 December 1968, KC PZPR 2664, pp. 90-91, AAN. 
conference. ${ }^{62}$ They showed how difficult it was for the Warsaw Pact to follow the NATO model in supplementing military consolidation with a political opening conducive to accommodation with the other side.

62 Record of the Budapest meeting of the PCC, 15 March 1969, ZPA J IV 2/202-264 Bd 16, SAPMO. 


\section{The Demise of the Warsaw Pact (1969-91)}

For both of the alliances, détente was a gamble of how to beat the rival in other than a military competition while keeping the arms race going but safely under control. In consolidating the Warsaw Pact, Moscow left open the question of how-or whether-the repressive and inefficient Soviet system could be changed to weather the competition. The ease with which it crushed the Czechoslovak reform movementwhich had attempted to address that question-gave the wary Soviet leaders little incentive to do the same. Their reform of the Warsaw Pact concerned all but exclusively its military dimensions.

The documents adopted in Budapest satisfied the Polish desire for enhancing the PCC and improving its procedures. Clarifying the previously nebulous division of power between the supreme commander and national governments, the national armed forces were left under their command in peacetime while their Soviet supervision was ensured through the PCC. At the same time, the establishment of the military council, committee of defense ministers, and committee on technology added three new entities of a military nature. ${ }^{63}$

The first resembled NATO's military committee by representing the member states through their chiefs of staff but differed from it by including the supreme commander as well, thus allowing guidance by Moscow. Moreover, the Warsaw Pact's Soviet chief of staff, with much expanded personnel, provided the council's executive mechanism while the committee on technology served as its agency in charge of research and development. The committee of defense ministers-who had been holding periodic sessions as a group before-was now formally constituted as an advisory body on defense policy, meeting at

63 Records of the Budapest meeting of the PCC, 15 March 1969, AZN 32854, pp. 6-57, BA-MA; AÚV KSČ 02/1/5513/32, SÚA. annual intervals. But the politically controversial plans for the creation of a committee of foreign ministers that would coordinate nonmilitary dimensions of policy were shelved, as were those for a permanent secretariat.

The resulting transformation of the Warsaw Pact from Khrushchev's onetime "cardboard castle" into a solid military structure initially served Soviet interests well. It led to the development in Eastern Europe of a multinational group of officers who, much like their NATO counterparts, had formed collegial ties while attending the same military schools and working within the structures of the alliance agencies. Deriving from it considerable privileges and prestige, they became firmly dedicated to it. By 1970, the Warsaw Pact was also accepted by NATO as its legitimate, if hostile, counterpart and interlocutor in arms control matters. ${ }^{64}$ In the longer term, however, the consequences of this development were mixed.

While facilitating the progress, albeit glacial, of arms control, thus nourishing faith in détente, the legitimation did not prevent the alliance from evolving in ways bound to undermine that faith. Worried that the Warsaw Pact was lagging behind NATO in its command, control, and communication structure, the Soviet military, never committed to détente, sought to remedy the deficiency at the very time détente reached its peak. In June 1973, they tried to supplement the regulations about the alliance's peacetime command with those that would give expanded powers to its supreme commander and ensure unrestricted control by the Moscow general staff in case of war. ${ }^{65}$ After predictable resistance by Romania and the unexpected confrontation with the United States during the October Middle East war, the Soviet Union subsequently chose not to press the issue. It did not, however, abandon it.

As détente faltered in the latter half of the nineteen-seventies, while the West was gaining in the nonmilitary competition, Moscow's initial

64 Final communiqué and annex, "Alliance Defence for the Seventies," 4 December 1970, NATO: Texts of Final Communiqués, 1949-1974 (Brussels: NATO Information Service, no date), pp. 243-53.

65 Report on Sofia meeting of chiefs of staff, 12-15 June 1973, VA-01/40359, pp. 1-36, BA-MA. 
impulse to amend the Warsaw Pact by making it more akin to NATO was reassuring. In trying to reinforce it against the perceived ideological assault, the Soviet Union sought to provide its missing political components, particularly the committee of foreign ministers and permanent secretariat. ${ }^{66}$ But while the former began to function in 1977 , the latter never did.

With the Kremlin's grip on Soviet military weakening during the last Brezhnev years, the Warsaw Pact's evolution took a disturbing turn. In 1980, Moscow finally pushed through the statute on its command in wartime that had been pending for so long. It justified this step by allluding to its strategy of seeking total defeat of the enemy in a total war-a strategy incongruous with NATO's - which required that all of the alliance's resources be put at the disposal of the supreme commander and his orders be strictly followed. 67 The submission of the document for approval without a discussion at the PPC meeting in Moscow made Ceausescu refuse to sign and angrily leave town. "This much for 'equality' and 'democracy' in deciding questions on which victory and defeat in war could hinge," the Warsaw Pact chief of staff, Gen. Anatolii I. Gribkov, commented in retrospect. ${ }^{6} 8 \mathrm{He}$ believed that, with more respect for the allies, full agreement could have been reached.

The adoption of the secret regulations, ${ }^{69}$ valid but not binding for Romania, raised justifiable doubts about Moscow's managerial ability three months after its invasion of Afghanistan invited questions about

66 Report on the Bucharest meeting of the PCC, 25-26 November 1976, MR C-20, I/31368, pp. 29-34, BA-B.

67 Statement by Gen. S.F. Romanov at the Sofia meeting of chiefs of staff, 12-14 June 1978, VA-01/40363, pp. 90-108, BA-MA.

68 Anatoli Gribkow, Der Warschauer Pakt: Geschichte und Hintergründe des östlichen Militürbündnisses (Berlin: Edition Q, 1995), pp. 46-47, quote on p. 47; Ryszard J. Kukliński, "Wojna z narodem widziana od środka" [The War against the Nation As Seen from the Center], Kultura [Paris] 475, no. 4 (April 1987): 3-57, at pp. 56-57.

69 "Grundsätze über die Vereinten Streitkräfte der Teilnehmerstaaten des Warschauer Vertrages und ihre Führungsorgane (für den Krieg)," 18 March 1980 , AZN 32854, pp. 85-120, BA-MA. of who really was in charge in the Kremlin. The subsequent appointment of the moribund Brezhnev as the Warsaw Pact's nominal commander-in-chief, likewise not approved by Romania, was accepted by the other party leaders "with sarcastic smiles" after the option of appointing them as his peers had been dropped. ${ }^{70}$ Although the communist alliance continued to impress the West by its apparent strength and real arrogance, its decline had already begun. It was not so much the question of matching the West in building the increasingly superfluous nuclear weapons as that of keeping up with rising Western preponderance in technologically advanced conventional armaments-a battle that Warsaw Pact commanders increasingly suspected was lost. ${ }^{71}$

Aware of the security dilemma the Soviet Union faced because of its provoking Western hostility ${ }^{72}$, the new Kremlin leader Iurii V. Andropov rightly grasped the political motives behind the armament buildup by the United States and its NATO partners. They want, he told the Warsaw Pact allies in 1983, to "radically change the international situation in their favor, so that they could dictate to us how to live and how to go about our affairs." 73 He reiterated the need for creating a permanent secretariat. ${ }^{74}$

Nothing was done to create it, however, by the time Adropov died a year later. Nor could anything constructive be expected from his

70 Gribkow, Der Warschauer Pakt, pp. 52-53, quote at p. 53; resolution on appointment, 30 April 1980, AZN 32854, p. 132, BA-MA.

71 Summary of speech by Kulikov for the Prague meeting of the PCC on 4-5 January 1983, AZN 30560, pp. 238-44, BA-MA; "Die Anstrengungen der NATO zur Erringung der militärtechnischen Überlegenheit bei den Streitkräften allgemeiner Bestimmung" [NATO Efforts at the Attainment of Technological Superiority in Conventional Forces], prepared for the 11 November 1985 session of the East German National Defense Council, DVW 1/39532, pp. 61-69, BA-MA

72 Memorandum of 10 January 1983 , quoted in Wjatscheslaw Daschitschew, "Außenund Sicherheitspolitik Rußlands gegenüber Europa," Berliner Europa-Forum 6 (1967), no. 6: 15-23, at pp. 19-20.

73 Speech by Andropov at the Moscow summit of 28 June 1983, MR C-20 I/3-1950, pp. $68-77$, at p. 68 , BA-B.

74 Speech by Andropov at the Prague meeting of the PCC on 4-5 January 1983, VA01/40473, pp. 44-62, at p. 61, BA-MA. 
decrepit successor, Konstantin U. Chernenko. Only in 1985 did the new party chief Mikhail S. Gorbachev begin to address the situation in a way suggestive of a willingness to meet the NATO challenge by taking it as a model. The recommendation by the Warsaw Pact's commission of experts to finally built up the secretariat while also creating a mechanism for the exchange of information about foreign policy pointed in that direction..$^{75}$

In April, Ceaușescu again lambasted as anachronistic the Soviet demands for military collaboration without proper political consultation. ${ }^{76}$ In the same month Egon Bahr, the confidant of West Germany's chancellor Willy Brandt, was visiting the Kremlin and, if his self-serving testimony is to be trusted, impressed Gorbachev by advocating an East-West "security partnership" and criticizing deterrence based on growing armaments. ${ }^{77}$ Whatever the importance of these impulses, Gorbachev and his entourage had enough opportunity to become exposed to new Western ideas about security as well as enough incentives to consider them seriously. As the cost of the Soviet Union's bloated military establishment weighed ever more heavily on the country while the Warsaw Pact prove unable to match the West's technological advantage, such innovative concepts as "defensive sufficiency," "nonthreatening defense," or "structural inability to attack" promised a solution. They seemed all the more attractive since they originated with NATO's left-wing critics, affecting its posture as well. ${ }^{78}$

In June 1986, Gorbachev told the Warsaw Pact allies that the "new quality" he wanted was more of political and economic rather than merely military collaboration. ${ }^{79}$ The shift conformed with not only the long-standing Romanian preferences but also the more recent desire of

75 Record of the Sofia meeting of the PCC, 22-23 October 1985, VA-01/40371, pp. 187 97, BA-MA.

76 Record of the Warsaw summit, 26 April 1985, MR C-20 I/3-2169, p. 31, BA-B.

77 Egon Bahr, Zu meiner Zeit (Berlin: Blessing, 1996), pp. 515-16.

78 Robert D. English, Russia Views the West: Intellectual and Political Origins of Soviet New Thinking (New York: Columbia University Press, 1999).

79 Report on the Budapest meeting of the PCC on 10-11 June 1986, MR C-20, I/32326, pp. 23-34, at p. 26, BA-B. the region's communist regimes to make use of the alliance as a shield in resisting Western pressure to improve their record on human rights. None other than the hardline leader of the militaristic East Germany, Erich Honecker, now replaced the Polish communists by taking the lead in efforts to both strengthen the alliance by introducing Western models and defuse the arms race by influencing NATO from within, particularly through forces in West Germany "inclined toward realism." 80

Together with the similarly disposed Czechoslovak regime, East Berlin proceeded to revive the Rapacki plan as a proposal for a "nuclear freecorridor" in Central Europe. 81 When a Polish initiative for exchanging visits with NATO parliamentarians brought delegations of the North Atlantic Assembly to Hungary, Poland, and even Czechoslovakia, Honecker also believed the time had come to create within the Warsaw Pact "some sort of a common parliament." 82 And to help streamline the Soviet bloc's creaky Council for Mutual Economic Assistance, he favored borrowing a leaf from Western Europe's thriving Common Market, so that a "United Socialist States of Europe" could eventually ensue. ${ }^{83}$

More to the point, Gorbachev adopted NATO's own proposal for a radical reduction of both alliances' conventional forces, at first suggesting cuts that would substantially reduce, though not yet abolish, the Warsaw Pact's quantitative superiority. He tried to reassure the West by directing his chief of staff, Marshal Sergei F. Akhromeev, to revise the

80 Speech by Oskar Fischer at the Sofia meeting of foreign ministers, 29-30 March 1988, MR C-20 I/3-2640 VVS B 2-355/88, pp. 82-97, at p. 89, BA-B.

81 Record of Honecker-Adamec conversation, 17-18 April 1989, MR C-20 I/3-2800, pp. 93-102, BA-B.

82 Record of the Bucharest meeting of foreign ministers, 14-15 October 1986, MR C20, I/3-2381, p. 179, BA-B; Richard Weitz, "NATO and the New Eastern Europe," Report on Eastern Europe, 24 May 1991, pp. 30-35, at pp. 30-31; note on HoneckerGorbachev conversation on 3 October 1986, ZPA J IV 2/201/1704, SAPMO.

83 Record of the Moscow meeting of the Council of Mutual Economic Assistance, 1618 May 1989, MR C-20 I/4-646 2191-225, BA-B; record of Honecker-Gorbachev conversation, 28 September 1988, ZPA J IV/935, SAPMO 
Soviet military doctrine, and rectify the imbalance of troops and armaments by changing their strategic posture. ${ }^{84} \mathrm{By}$ shifting from an offensive to a defensive strategy, thus adapting the Warsaw Pact to NATO, he sought to make their accommodation easier. Approved at the Berlin meeting of the PCC in May 1987, the new military doctrine was made public. ${ }^{85}$

Real rather than cosmetic, the change was nothing short of revolutionary. It confirmed NATO's long-standing assumption that until then the Warsaw Pact had been poised to attack. Having previously justified its posture by NATO's alleged aggressive intentions, the revised doctrine still presumed a hypothetical assault from the West but called for defending against it on home rather than enemy territory. Unable to explain the contradiction, Soviet officers briefed their Eastern European allies that the new posture was right even if it would give an advantage to the aggressor. ${ }^{86}$ To justify itself to the outside world, the alliance subsequently decided to establish an information office ${ }^{87}$ something NATO always maintained for both practical and philosophical reasons but for its adversary was a risky innovation.

When Gribkov and his staff proceeded to revise the 1980 regulations about command structure in wartime to make them conform to the new doctrine, the revision amounted to only insubstantial changes. ${ }^{88}$ It showed how fundamentally unprepared the communist alliance was for its intended adaptation to the NATO model. Despite their grudging acceptance of the new posture, the military fretted about it. They cited environmental damage that would result from having to use more land

84 Sergei F. Akhromeev and Georgii M. Kornienko, Glazami Marshala i Diplomata [Through the Eyes of a Marshal and a Diplomat] (Moscow: Mezhdunarodnye otsheniia, 1992), pp. 121-26.

85 Report of the Berlin meeting of the PCC on 28-29 May 1987, MR C-20, I/3-2477, pp. 32-41, BA-B; statement on the doctrine, VA-01/40373, pp. 4-11, BA-MA.

86 Summary of the Moscow meeting of chiefs of staff on 14 October 1987, AZN 32659 , pp. 65-71, BA-MA.

87 Vacek to Czechoslovak Ministry of Defense, 29 February 1988, GŠ-OS 1988, 002010, AMO; Gribkov to Streletz, 11 March 1988, DVW1/44535, BA-MA.

88 Draft of revised statute with explanations, 11 March 1988, VA-01/40409, pp. 30-52, 129-31, BA-MA. for defense than was required to launch an offensive. ${ }^{89}$ Supreme commander Marshal Viktor G. Kulikov continued to insist that "the only possibility of destroying the enemy in case of an aggression consists in decisive attack operations in the form of a counter-offensive" into enemy territory..$^{90}$ At the end of 1988 , he, Gribkov, and other stalwarts of the old regime were summarily dismissed by Gorbachev and replaced by officers he mistakenly regarded as more congenial.

Gorbachev wanted the Eastern European leaders to believe that "the initiative is in our hands" and a favorable "shift in world opinion" had already been accomplished. ${ }^{91}$ In fact, he was on a slippery slope and the shift he was referring to sounded a death knell for the Warsaw Pact. In moving it closer to NATO to facilitate the conclusion of agreements on force reductions, he made the secretive alliance provide for the first time accurate, rather than incomplete or distorted, data about its numerical strength, and allow them to be verified by inspections. ${ }^{92}$ Gorbachev accepted the Western position that the reductions must be asymmetrical to abolish disparities favoring the Warsaw Pact, and proceeded to rectify them unilatarally. Kulikov's successor Gen. Petr G. Lushev was aghast at the "destruction of the present structure of the Unified Armed Forces" while NATO remained intact, predicting that the result will be not parity but new imbalances and asymmetries. ${ }^{93}$

Lushev was right. The implementation by the Warsaw Pact of its defensive doctrine prefigured its demise. Trying to change itself in NATO's

89 Record of meeting with the Czechoslovak chief of combat preparation, 30 August 1988, MNO SPB 1988, 436/14, AMO.

90 Record of Kulikov-Honecker conversation, 27 June 1988, VA-01/40374, pp. 66-73, BA-MA.

91 Report on Gorbachev-Honecker meeting, 11 December 1987, MR C-20 I/3-2581, pp. $42-47$, at p. 45 , BA-B.

92 Summary of the Moscow meeting with representatives of the Soviet general staff and foreign ministry on 17 May 1988, AZN 32661, pp. 85-88, BA-MA; Soviet-East German-Czechoslovak agreement on inspections under the INF treaty, 1 June 1988, MR C-20 I/3-2674, pp. 143-62, BA-B.

93 Speech by Lushev at the Bucharest meeting of the PCC, 7-8 July 1989, VA01/40375, pp. 23-35, BA-MA. 
image proved its undoing. Nor could its attempted transformation into a mainly political grouping save it. There was an air of make-believe about the frantic debates conducted at its last meetings by the communist officials scurrying to refurbish the alliance with political institutions while the crucial developments that eventually broke their power were taking place elsewhere. ${ }^{94}$

Although the structural crisis resulting from the attempt to alter the Warsaw Pact against its nature was not the primary cause of its demise, once the forces that sustained it had been weakened for other reasons, the alliance was doomed. And yet, when Eastern Europe's communist regimes collapsed at the end 1989, the desirability of dismantling it was not immediately self-evident. At the Malta meeting with President George Bush in December of that year, Gorbachev still professed a readiness to salvage the Warsaw Pact by remodeling it after NATO.

More surprisingly, Poland's new anti-communist government initially favored the preservation of a reformed Warsaw Pact as a safeguard against unpredictable consequences of German unification, and only dropped this untenable position in $1991 .{ }^{95}$ And in the West, the successful negotiation of the Vienna CFE agreement on the reduction of conventional forces between the two alliances nourished the illusion that they together might best guarantee Europe's future security. Most amazing, war games enacting the defense of East Germany by Warsaw Pact forces against an imaginary NATO attack continued even under the country's democratically-elected government as late as June $1990 .{ }^{96}$

Records of the Berlin meeting of foreign ministers, 11-12 April 1989, MR C-20 I/3 2800, BA-B, of the Bucharest meeting of the PCC, 7-8 July 1989, MR C-20 I/3-2840, pp. 34-215, BA-B, of the Warsaw meeting of foreign ministers, 26-27 October 1989 MR C-20, I/3-2863, pp. 27-148, and of the Sofia meeting of chiefs of staff, 30 October-2 November 1989, VA-01/40364, BA-MA.

95 Louisa Vinton, "Domestic Politics and Foreign Policy," in Polish Foreign Policy Reconsidered: Challenges of Independence, ed. Ilya Prizel and Andrew A. Michta (New York: St. Martin's Press, 1995), pp. 23-71, at pp. 36-44.

96 Lothar Rühl, "Offensive Defence in the Warsaw Pact," Survival 33 (1991): 442-50, at p. 448 .
By 1991, however, all attempts to salvage the Warsaw Pact as either a military or a political grouping of equal members had failed. In July, the alliance was dissolved, without ever coming close to becoming another NATO. In a symbolic postscript, the executor of Gorbachev's self-destructive revision of its military doctrine, Marshal Akhromeev, shot himself after having participated in the abortive conspiracy intended to reverse the course by unseating Gorbachev. But Gorbachev himself, having presided over the historic change, never seemed to understand what really happened. 


\section{Conclusions}

The more the Cold War recedes into the past, the more it is obvious that Moscow's allies were able and willing to contest its supremacy more extensively than the old-fashioned stereotype of an almighty Soviet Union suggests. This does not necessarily mean that the Warsaw Pact's collapse-or NATO's survival-was preordained. Not only is the answer to that question, posed with the benefit of hindsight, more within the realm of theology than of political science, but it also is of limited use in explaining the motives and aspirations of contemporaries who could not know that the collapse was coming and certainly did not act on this assumption.

The most pertinent case in point is that of the Polish communists, whose consistency in trying to maintain a strong Warsaw Pact responsive to their needs may come as a surprise. Whether they were mainly motivated by the desire to keep their power with Soviet help or sought to uphold their country's interests against Soviet encroachments as best as they could became a subject of lively debate in Poland once the Cold War was over. ${ }^{97}$ The Warsaw Pact evidence suggests that both considerations were intermingled in their efforts to make their country-and themselves as its self-appointed rulers-the most respected and influential among Moscow's allies and, with it rather than against it, make Poland more secure against perceived German threat-one of the few goals they had in common with most of their subjects. This ambivalent legacy helps to understand both the initial reluctance of Poland's postcommunist government to part with the Warsaw Pact as long as its transformation into a democratic alliance of equals seemed possible and the eagerness with which the nation's rank and file embraced the alternative of joining NATO as soon as that possibility proved an illusion.

97 Spór o PRL [The Controversy about People's Poland] (Cracow: Znak, 1996).
Insight into the inner workings of the communist alliance retrospectively reduces the importance of the Romanian dissidence, which used to excite Western observers so much. In a longer perspective, Romania's efforts to paralyze the Warsaw Pact appear less significant than the Soviet ability to contain them with help from its other members, notably Poland. Within that context, France's severance of its ties with NATO and NATO's ability to absorb the shock and even thrive as a result, therefore provided an example not so much to the Romanians, who had already started going their separate way for other reasons, as to the Soviet Union. Its ability to run the alliance despite obstruction by one of its members in turn provides a timely lesson for NATO, namely that of how a "coalition of the willing" could better ensure effective performance than could a vain quest for an elusive consensus.

Most importantly, the multifaceted story of NATO as a model for the Warsaw Pact highlights the pitfalls of the latter's attempting to remake itself along the lines of its rival. Conceivably, the attempt at the transformation of an alliance relying ultimately upon coercion into one functioning by voluntary collaboration could never have worked under the Soviet system. But the more pertinent object lesson is that tampering with a military alliance by trying to make it into something else can be fatal. Such a lesson is of abiding relevance for a NATO still trying to redefine itself once the Soviet threat is gone and, as its less than stellar performance in the war against Serbia has shown, while its efficacy in dealing with other threats is in doubt. Even so, NATO's ultimate raison d'être remains its particular capacity to maintain international security by wielding military power, rather than by preventive diplomacy and other useful means short of force that other organizations have more or less successfully specialized in. By preserving its central military function after all the necessary adjustments have been made, the Western alliance could best avoid the fatal error that precipitated the demise of its Cold War adversary. 


\section{Abbreviations}

AAN Modern Records Archives [Archiwum Akt Nowych], Warsaw

AMO Archives of the Ministry of Defense [Archív Ministerstva obrany], Prague

AÚV KSČ Archives of the Central Committee of the Communist Party of Czechoslovakia [Archív Ústředního výboru Komunistické strany Československa]

AVPRF Foreign Policy Archives of the Russian Federation [Arkhiv vneshnei politiki Rossiiskoi Federatsii]

BA-B Bundesarchiv, Berlin

BA-MA Bundesarchiv-Militärarchiv, Freiburg

FRUS Foreign Relations of the United States

GŠ-OS Operations Department of the General Staff [Operační správa Generálního štábu]

KC PZPR Central Committee of the Polish United Workers' Party [Komitet Centralny Polskiej Zjednoczonej Partii Robotniczej]

MR Ministerrat [der Deutschen Demokratischen Republik

SAPMO Stiftung der Parteien und Massenorganisationen der DDR im Bundesarchiv, Berlin
SÚA

Central State Archives [Státní ústřední archív], Prague

VKO Military Defense Commission [Vojenská komise obrany]

ZPA Zentrales Parteiarchiv [der Sozialistischen Einheitspartei Deutschlands] 


\section{BIBLIOGRAPHY}

\section{Archives}

\section{Czech Republic}

Archives of the Central Committee of the Communist Party of Czechoslovakia [Archív Ústředního výboru Komunistické strany Československa], Prague

Archives of the Ministry of Defense [Archív Ministerstva obrany], Prague

Central State Archives [Státní ústřední archív], Prague

\section{Germany}

Bundesarchiv, Berlin

Bundesarchiv-Militärarchiv, Freiburg

Stiftung der Parteien und Massenorganisationen der DDR im Bundesarchiv, Berlin

\section{Russia}

Foreign Policy Archives of the Russian Federation [Arkhiv vneshnei politiki Rossiiskoi Federatsii], Moscow

\section{Poland}

Modern Records Archives [Archiwum Akt Nowych], Warsaw

\section{Published Sources, Books, and Articles}

Akhromeev, Sergei F. and Georgii M. Kornienko. Glazami Marshala $i$ Diplomata [Through the Eyes of a Marshal and a Diplomat]. Moscow: Mezhdunarodnye otsheniia, 1992.

Albert, Andrzej. Najnowsza historia Polski, 1918-1980 [Poland's Contemporary History]. London: Puls, 1991.

Bahr, Egon. Zu meiner Zeit. Berlin: Blessing, 1996.

Benčík, Antonín. Operace "Dunaj”: Vojáci a Pražské jaro 1968: Studie a dokumenty [Operation 'Danube': The Military and the 1968 Prague Spring: Studies and Documents]. Prague: Ústav pro soudobé dějiny AV CR, 1994.

Daschitschew, Wjatscheslaw. „Außen- und Sicherheitspolitik Rußlands gegenüber Europa." Berliner Europa-Forum 6 (1967): 15-23.

Documents on International Affairs 1955, ed. by Noble Frankland. London: Oxford University Press, 1958.

Dunn, Keith A. Soviet Perceptions of NATO. Carlisle Barracks: U.S. Army War College, 1978.

Egorova, Nataliia I. "NATO i evropeiskaia bezopasnost: Vospriiatie sovetskogo rukovodstva" [NATO and European Security: Soviet Leadership Perceptions]. In Stalin $i$ kholodnaia voina [Stalin and the Cold War], ed. by Aleksandr O. Chubarian, Ilia V. Gaiduk, and Nataliia I. Egorova. Moscow: Institut vseobshchei istorii RAN, 1998: 291-314.

Egorova, Nataliia I. "Soviet Perceptions of the Formation of NATO, 1948-1953." Paper presented at the Norwegian Nobel Institute. Oslo: March 1998.

English, Robert D. Russia Views the West: Intellectual and Political Origins of Soviet New Thinking. New York: Columbia University Press, 1999.

Ermarth, Fritz. Internationalism, Security, and Legitimacy: The Challenge to Soviet Interests in East Europe, 1964-1968. Santa Monica: RAND, 1969. 
Evangelista, Matthew. “Why Keep Such an Army?”: Khrushchev's Troop Reductions. Working Paper no. 19, Cold War International History Project. Washington: Woodrow Wilson International Center for Scholars, 1997.

Garthoff, Raymond L. "When and Why Romania Distanced Itself from the Warsaw Pact." Cold War International History Project Bulletin 5 (1995): 111.

Gribkow, Anatoli. Der Warschauer Pakt: Geschichte und Hintergründe des östlichen Militärbündnisses. Berlin: Edition Q, 1995.

Haftendorn, Helga. NATO and the Nuclear Revolution: A Crisis of Credibility, 1966-1967. Oxford: Clarendon Press, 1996.

Ihme-Tuchel, Beate. Das "nördliche Dreieck": Die Beziehungen zwischen der DDR, der Tschechoslowakei und Polen in den Jahren 1954 bis 1962. Cologne: Wissenschaft und Politik, 1994.

Kramer, Mark. "The 'Lessons' of the Cuban Missile Crisis for Warsaw Pact Nuclear Operations." Cold War International History Project Bulletin 5 (1995): 59, 110-115, 160.

Kukliński, Ryszard J. "Wojna z narodem widziana od środka" [The War against the Nation As Seen from the Center], Kultura 475, no. 4 (Paris: April 1987): 3-57.

Lós-Nowak, Teresa. "Geneza planu Rapackiego utworzenia strefy bezatomowej w Ewropie środkowej: źrodła motywacyjne, podstawowe założenia i cele," [The Genesis of Rapacki's Plan of Nuclear-Free Zone in Central Europe: Motives, Principles, and Goals]. In Plan Rapackiego a Bezpieczeństwo Europejskie [The Rapacki Plan and European Security]. Wrocław: Wydawnictwo Uniwersytetu Wrocławskiego, 1991.

Lós-Nowak, Teresa. Polskie inicjatywy $w$ sprawie broni nuklearnej $w$ Europie środkowej, 1957-1964 [Polish Initiatives Concerning Nuclear Weapons in Central Europe, 1957-1964]. Wrocław: Wydawnictwo Uniwersytetu Wrocławskiego, 1989.

Vojtech Mastny, "The Soviet Union and the Origins of the Warsaw Pact in 1955," in Mechanisms of Power and Soviet Union, ed. Niels Erik Rosenfeldt,
Bendt Jensen, Erik Kulavig (Houndmills, Basingstoke: Macmillan, 2000): 241-266.

Mastny, Vojtech. “'We Are in a Bind': Polish and Czechoslovak Attempts at Reforming the Warsaw Pact, 1956-1969." Cold War International History Project Bulletin 11 (1998): 230-50.

Narinski, Mikhail. "Les soviétiques et la decision française." In France et l'OTAN, 1949-1996, ed. by Maurice Vad'sse, Pierre Melandri, and Frédéric Bozo. Brussels: Complexe, 1996: 503-16.

NATO: Basic Documents. Brussels: NATO Information Service, 1989.

NATO: Texts of Final Communiqués, 1949-1974. Brussels: NATO Information Service, no date.

Pikhoia, Rudolf G. "Chekhoslovakiia, 1968 god, vzgliad iz Moskvy: Po dokumentam TsK KPSS" [Czechoslovakia 1998: The View from Moscow after Documents of the Central Committee of the CPSU]. Novaia i noveishaia istoriia 6 (1994): 3-20.

Pióro, Tadeusz. Armja ze skaza: W Wojsku Polskim 1945-1968 (wspomnienia i refleksje) [The Defective Army: In the Polish Army, 1945-1968 (Memories and Reflections)]. Warsaw: Czytelnik, 1994.

Rice, Condoleezza. The Soviet Union and the Czechoslovak Army, 19481983: Uncertain Allegiance. Princeton: Princeton University Press, 1984.

Rühl, Lothar. "Offensive Defence in the Warsaw Pact." Survival 33 (1991): 442-50.

Selvage, Douglas E. "Poland, the German Democratic Republic and the German Question, 1955-1967.' unpublished Ph.D. diss. Yale University, 1998.

Spencer, Robert. "Alliance Perceptions of the Soviet Threat, 1950-1988." In The Changing Western Analysis of the Soviet Threat, ed. by CarlChristoph Schweitzer. London: Pinter, 1990: 9-48.

Spór o PRL [The Controversy about People's Poland]. Cracow: Znak, 1996. 
Suciu, Mircea. "Criza rachetelor din Cuba și apropierea româno-americană" [The Cuban Missile Crisis and the Romanian-American Rapprochement]. Dosarele istoriei 6. Bucharest: 1997: 30-31.

Vinton, Louisa. "Domestic Politics and Foreign Policy." In Polish Foreign Policy Reconsidered: Challenges of Independence, ed. by Ilya Prizel and Andrew A. Michta. New York: St. Martin's Press, 1995: 23-71.

Wandycz, Piotr S. "Adam Rapacki and the Search for European Security." In The Diplomats, 1939-1979, ed. by Gordon A. Craig and Francis L. Loewenheim. Princeton: Princeton University Press, 1994: 289-317.

Weitz, Richard. "NATO and the New Eastern Europe." Report on Eastern Europe. 24 May 1991:30-35. 


\section{In der gleichen Publikationsreihe sind erschienen:}

Nr. 1 Kurt R. Spillmann: Konfliktforschung und Friedenssicherung (1987) vergriffen

Nr. 2 Kurt R. Spillmann: Beyond Soldiers and Arms: The Swiss Model of Comprehensive Security Policy (1987)

Nr. 3 Kurt R. Spillmann: Die Kubakrise von 1962: geschichtliche, politische und strategische Hintergründe (1987) vergriffen

Nr. 4 Beat Näf / Kurt R. Spillmann: Die ETH-Arbeitstagung zur schweizerischen Sicherheitspolitik vom 29. Juni 1987 - Bericht und Auswertung (1987)

Nr. 5 Beat Näf / Kurt R. Spillmann: Die ETH-Arbeitstagung zur schweizerischen Sicherheitspolitik vom 7. Dezember 1987 - Bericht und Auswertung (1988)

Nr. 6 Jacques Freymond: La menace et son évolution dans les domaines militaires et civils dans l'optique de la recherche scientifique et universitaire (1988)

Nr. 7 Christian Kind: Extended Deterrence - Amerikas Nukleargarantie für Europa (1989)

Nr. 8 Franz Martin Aebi: Der Weg zum Weiterleben - Morphologische Studie zu einer zeitgemässen Planung einer Strategie der staatlichen und gesellschaftlichen Selbstbehauptung (1989)

Nr. 9 Madeleine Hösli / Kurt R. Spillmann: Demographie und Sicherheitspolitik: Nationale Aspekte - Bericht und Auswertung der ETH-Arbeitstagung vom 5. Dezember 1988 (1989)

Nr. 10 Richard D. Challener: John Foster Dulles: The Certainty/Uncertainty Principle (1989)

Nr. 11 Dominique Wisler: Vers une nouvelle politique de sécurité (1989) vergriffen

Nr. 12 Kurt R. Spillmann und Kati Spillmann: Feindbilder: Entstehung, Funktion und Möglichkeiten ihres Abbaus (1989)

Nr. 13 Madeleine Hösli / Kurt R. Spillmann: Demographie und Sicherheitspolitik: Rückwirkungen internationaler Entwicklungen auf die Schweiz - Bericht und Auswertung der ETH-Arbeitstagung vom 8. Juni 1989 (1989)

Nr. 14 Fred Tanner: Die Schweiz und Rüstungskontrolle: Grenzen und Möglichkeiten eines Kleinstaates (1990)

Nr. 15 Jacques Hürlimann / Kurt R. Spillmann: Der Bericht 90 zur schweizerischen Sicherheitspolitik im Urteil ausländischer Expertinnen und Experten - Bericht und Auswertung der ETH-Arbeitstagung vom 6. Dez. 1990 (1991)
Nr. 16 Urs Roemer: Die Strategie der „Flexible Response“ und die Formulierung der amerikanischen Vietnampolitik unter Präsident Kennedy (1991)

Nr. 17 Michael Fajnor: Die europäische Integration und ihre sicherheitspolitischen Folgen für die Schweiz (1991)

Nr. 18 Christof Buri / Karl W. Haltiner / Kurt R. Spillmann: Sicherheit 1991 - Ergebnisse einer Repräsentativbefragung (1991)

Nr. 19 Andreas Wenger: Kontinuität und Wandel in der amerikanischen Nuklearstrategie Präsident Eisenhowers Strategie der massiven Vergeltung und die nuklearstrategische Neuevaluation der Administration Kennedy (1991)

Nr. 20 Kurt R. Spillmann (Hrsg.): Zeitgeschichtliche Hintergründe aktueller Konflikte I Vorlesung für Hörer aller Abteilungen - Sommersemester 1991 (1991) vergriffen

Nr. 21 Stephan Kux: Decline and Reemergence of Soviet Federalism (1991) vergriffen

Nr. 22 Kurt R. Spillmann (Hrsg.): Europäische Integration und Schweizerische Sicherheitspolitik - Bericht und Auswertung der ETH-Arbeitstagung vom 25./26. Oktober 1991 (1992)

Nr. 23 Anton Bebler: The Yugoslav Crisis and the „Yugoslav People's Army“ (1992) vergriffen

Nr. 24 Sabina Ann Fischer: Namibia Becomes Independent - The U.S. contribution to regional peace (1992)

Nr. 25 Dominique Wisler: La violence politique en Suisse et les mouvements sociaux: 1969-1990 (1992)

Nr. 26 Mauro Mantovani: Stand und Perspektiven der Sicherheitspolitik in Europa (1992)

Nr. 27 Kurt R. Spillmann (Hrsg.): Zeitgeschichtliche Hintergründe aktueller Konflikte II Vorlesung für Hörer aller Abteilungen - Sommersemester 1992 (1992)

Nr. 28 Kurt R. Spillmann und Mauro Mantovani (Hrsg.): Die sicherheitspolitische Integration in Europa als Herausforderung für die Schweiz - Bericht und Auswertung der ETHArbeitstagung vom 26. Oktober 1992 (1993)

Nr. 29 Günther Bächler: Bosnien-Herzegowina - Friedliche Streitbeilegung zwischen Realität und konkreter Utopie (1993) vergriffen

Nr. 30 Ilja Kremer: Die Sowjetunion und Russland nach 1985: Von der Oktoberrevolution zur Oktoberkrise (1993)

Nr. 31 Kurt R. Spillmann (Hrsg.): Zeitgeschichtliche Hintergründe aktueller Konflikte III Vorlesung für Hörer aller Abteilungen - Sommersemester 1993 (1994) vergriffen 
Nr. 32 Karl W. Haltiner / Kurt R. Spillmann: Öffnung oder Isolation der Schweiz? Aussenund sicherheitspolitische Meinungsbildung im Trend (1994)

Nr. 33 Mauro Mantovani: Nato-Mitglied Schweiz? Voraussetzungen und Folgen einer sicherheitspolitischen Integration der Schweiz (1994)

Nr. 34 Michael Fajnor: Multilaterale Anstrengungen zur Kontrolle konventioneller Rüstungstransfers und die Schweiz (1994)

Nr. 35 Kurt R. Spillmann (Hrsg.): Zeitgeschichtliche Hintergründe aktueller Konflikte IV Vorlesung für Hörer aller Abteilungen - Sommersemester 1994 (1994)

Nr. 36 Andreas Wenger / Jeronim Perovic: Das schweizerische Engagement im ehemaligen Jugoslawien (1995)

Nr. 37 Kurt R. Spillmann (Hrsg.): Zeitgeschichtliche Hintergründe aktueller Konflikte V Vorlesung für Hörer aller Abteilungen - Sommersemester 1995 (1995)

Nr. 38 Karl W. Haltiner / Luca Bertossa / Kurt R. Spillmann: Internationale Kooperationsbereitschaft und Neutralität: Aussen- und sicherheitspolitische Meinungsbildung im Trend (1996)

Nr. 39 Ulrich Gerster / Regine Helbling: Krieg und Frieden in der bildenden Kunst (1996) Ulrich Gerster / Regine Helbling: Krieg und Frieden in der bildenden Kunst (1996) (Bildteil)

Nr. 40 Christoph Breitenmoser: Sicherheit für Europa: Die KSZE-Politik der Schweiz bis zur Unterzeichnung der Helsinki-Schlussakte zwischen Skepsis und aktivem Engagement (1996)

Nr. 41 Laurent F. Carrel / Otto Pick / Stefan Sarvas / Andreas Schaer / Stanislav Stach: Demokratische und zivile Kontrolle von Sicherheitspolitik und Streitkräften (1997)

Nr. 42 Karl W. Haltiner / Luca Bertossa / Kurt R. Spillmann: Sicherheit '97 (1997)

Nr. 43 Andreas Wenger / Jeronim Perovic: Russland und die Osterweiterung der Nato: Herausforderung für die russische Aussen- und Sicherheitspolitik (1997)

Nr. 44 Kurt R. Spillmann (Hrsg.): Zeitgeschichtliche Hintergründe aktueller Konflikte VI Vorlesung für Hörer aller Abteilungen - Sommersemester 1997 (1997)

Nr. 45 Kurt R. Spillmann und Hans Künzi (Hrsg.): Karl Schmid als strategischer Denker: Beurteilungen aus historischer Perspektive. Bericht und Auswertung der Tagung vom 1. Juli 1997 (1997)

Nr. 46 Derek Müller: Die Aussen- und Sicherheitspolitik der Ukraine seit 1990/91: Herausforderungen, Leistungen und Perspektiven (1998)
Nr. 47 Andreas Wenger und Jeronim Perovic: Russland zwischen Zerfall und Grossmachtanspruch: Herausforderungen der Regionalisierung (1998)

Nr. 48 Andreas Wenger, Christoph Breitenmoser, Patrick Lehmann: Die Nato-Partnerschaft für den Frieden im Wandel: Entwicklung und Zukunft eines kooperativen Sicherheitsinstrumentes (1998)

Nr. 49 Christof Münger: Ich bin ein West-Berliner: Der Wandel der amerikanischen Berlinpolitik während der Präsidentschaft John F. Kennedys (1999)

Nr. 50 Christian Nünlist: Kennedys rechte Hand: McGeorge Bundys Einfluss als Nationaler Sicherheitsberater auf die amerikanische Aussenpolitik 1961-63 (1999)

Nr. 51 David C. Atwood / Shahram Chubin / Pál Dunay / Jozef Goldblat / Martin Schütz / Heiner Staub: Arms Control and Disarmament: Revised version of papers Papers Presented at the $3^{\text {rd }}$ International Security Forum Zurich, 19-21 October 1998 (1999)

Nr. 52 Andreas Wenger: Herausforderung Sicherheitspolitik: Europas Suche nach Stabilität (1999)

Nr. 53 Kurt R. Spillmann / Andreas Wenger / Stephan Libiszewski / Patrik Schedler: Informationsgesellschaft und schweizerische Sicherheitspolitik (1999)

Nr. 54 Kurt R. Spillmann / Andreas Wenger (Hrsg.): Zeitgeschichtliche Hintergründe aktueller Konflikte VII - Vortragsreihe an der ETH-Zürich - Sommersemester 1999 (1999)

Nr. 55 Daniel Möckli: Neutralität, Solidarität, Sonderfall: Die Konzeptionierung der schweizerischen Aussenpolitik der Nachkriegszeit, 1943-1947 (2000)

Nr. 56 Andreas Wenger / Jeremi Suri: The Nuclear Revolution, Social Dissent, and the Evolution of Détente: Patterns of Interaction, 1957-74 (2000)

Nr. 57 Jon A. Fanzun / Patrick Lehmann: Die Schweiz und die Welt: Aussen- und sicherheitspolitische Beiträge der Schweiz zu Frieden, Sicherheit und Stabilität, 1945-2000 (2000)

Eine Gesamtübersicht über alle bisher erschienenen ,Zürcher Beiträge zur Sicherheitspolitik und Konfliktforschung “ ist einsehbar im Internet unter www.fsk.ethz.ch.

Die Beiträge können bei der Forschungsstelle für Sicherheitspolitik und Konfliktanalyse , ETH-Zentrum SEI, CH-8092 Zürich, Tel. 01/632 40 25, Fax: 01/632 19 41, bezogen werden. 


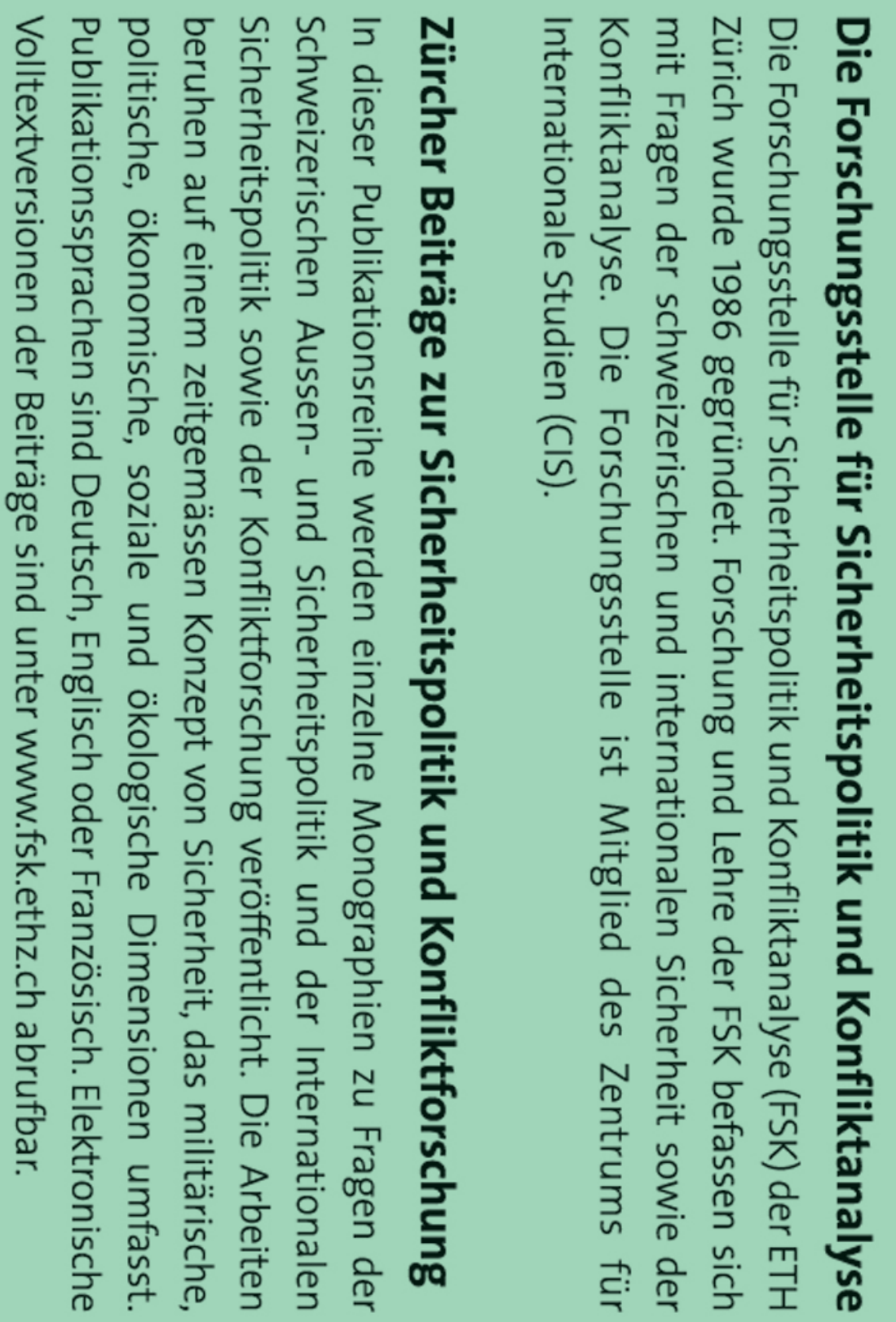

